\section{Hepatitis bij gebruik van glafenine}

\section{Mededeling van het Bureau Bijwerkingen Geneesmiddelen ${ }^{1}$}

\section{ABSTRACT}

Five case-histories have been reported to the Netherlands Centre for Monitoring of Adverse Reactions to Drugs concerning patients with hepatitis, attributed to the use of glafenine (including two previously published cases). In three patients the reaction occurred at more than one occasion.

Practitioners are earnestly requested to report analogous cases.

Het Bureau Bijwerkingen Geneesmiddelen heeft vijf meldingen ontvangen van hepatitis, ontstaan tijdens of kort na het gebruik van het analgeticum glafenine (Glifanan ${ }^{\circledR}$ ). Twee van deze patiënten werden eerder beschreven (YPMA e.a. 1978). De patiënten - vijf vrouwen, variërend in leeftijd van $3 I$ tot 79 jaar - vertoonden verschijnselen van hepatitis zoals misselijkheid, anorexie en icterus; transaminasen, alkalische fosfatase en bilirubine in het serum waren verhoogd. Bij alle patiënten werd glafenine als de waarschijnlijke oorzaak beschouwd. De afwijkingen verdwenen in het verloop van I-4 maanden na staken van glafenine.

Biopsie toonde hepatitis met fibrose, en in enkele gevallen centrilobulaire necrose met eosinofiele infiltratie. Bij drie patiënten bleek deze, aanvankelijk niet met glafenine in verband gebrachte, reactie eerder te zijn opgetreden; in één geval zelfs tweemaal.

\footnotetext{
${ }^{1}$ Mededelingen van het Bureau Bijwerkingen Geneesmiddelen (Staatstoezicht op de Volksgezondheid, Leidschendam) zijn gebaseerd op, door artsen gemelde, vermoede bijwerkingen van geneesmiddelen.
}

Geen van de patiënten nam meer dan de maximaal aanbevolen dosering. De duur van het gebruik liep uiteen van een week tot enkele maanden.

Drie patiënten hadden tevens andere geneesmiddelen gebruikt (zie tabel I). Gezien de tijdsrelatie met de hepatitis was glafenine echter de meest aannemelijke oorzaak.

TABEL I

\begin{tabular}{|c|c|c|}
\hline $\begin{array}{l}\text { Leeftijd/ } \\
\text { geslacht }\end{array}$ & Overige geneesmiddelen & $\begin{array}{l}\text { Hepatitis na } \\
\text { glafenine }\end{array}$ \\
\hline I. $33 / \mathrm{V}$ & geen & tweemaal \\
\hline 2. $50 / \mathrm{V}$ & geen & eenmaal \\
\hline 3. $3 I / V$ & orale anticonceptie & driemaal \\
\hline 4. $79 / \mathrm{V}$ & $\begin{array}{l}\text { amoxicilline, digoxine, } \\
\text { butylscopolamine, } \\
\text { insuline }\end{array}$ & eenmaal \\
\hline 5. $74 / \mathrm{V}$ & $\begin{array}{l}\text { propranolol, furosemide, } \\
\text { nitrazepam, ibuprofen }\end{array}$ & tweemaal \\
\hline
\end{tabular}

Om inzicht te verkrijgen in de aard en incidentie van deze mogelijke bijwerking van glafenine, verzoekt het Bureau Bijwerkingen Geneesmiddelen alle artsen om eventuele gegevens hieromtrent door te geven.

\section{Dankbetuiging}

Met dank aan de collegae R. TH. J. M. YPMA, L. VAN LEEUWEN en G. J. H. DEN OTTOLANDER, die door huñ meldingen deze publikatie mogelijk hebben gemaakt.

\section{LITERATUUR}

YPMA, R. TH. J. M., J. J. M. FESTEN en C. D. DE BRUIN (1978) Hepatotoxicity of Glafenine, Lancet II, 480-48I.

B. H. CH. STRICKER

R. H. B. MEYBOOM 